\title{
Uji daya hambat ekstrak biji pala (myristicae fragrans)terhadap pertumbuhan bakteri staphylococcus aureus dan streptococcus pyogenes
}

\author{
${ }^{1}$ Praisia M. E. Rumopa \\ ${ }^{2}$ Henoch Awaloei \\ ${ }^{2}$ Christi Mambo
}

\author{
${ }^{1}$ Kandidat Skripsi Fakultas Kedokteran Universitas Sam Ratulangi Manado \\ ${ }^{2}$ Bagian Farmakologi dan Terapi Fakultas Kedokteran Universitas Sam Ratulangi Manado \\ Email: rumopapem@gmail.com
}

\begin{abstract}
People of Indonesia especially in North Sulawesi often use nutmeg powder for wound treatment. Comensalist bacterias that live in human skin, like Staphylococcus aureus and Streptococcus pyogenescan infect open wound especially those that are not treatedwell. This study aimed to find out the result of nutmeg extract inhibition test on Staphylococcus aureus and Streptococcus pyogenes. This was a laboratory experimental study using modified Kirby-Bauer wells at Phytochemistry and Micobriology Laboratory of Sam Ratulangi University Faculty of Mathematics and Science. Nutmeg extract was obtained from maceration process with $96 \%$ ethanol. Concentrations of the thick extract that was used were $100 \mathrm{mg} / \mathrm{ml}, 50 \mathrm{mg} / \mathrm{ml}, 25 \mathrm{mg} / \mathrm{ml}$, and $12,5 \mathrm{mg} / \mathrm{ml}$. Cefuroxime was used as positive control and aquades was used as negative control. The results showed that aquades had no inhibition zone. Cefuroxime had the widest diameter of inhibition zone. The average of inhibition diameter that was produced by Cefuroxime was $37,33 \mathrm{~mm}$ toward S. Aureus bacteria and 42,67 mm toward S. Pyogenes bacteria. Nutmeg extract with $100 \mathrm{mg} / \mathrm{ml}$ concentration produced a $25,16 \mathrm{~mm}$ inhibition zone diameter on S. Aureus bacteria and $24,16 \mathrm{~mm}$ on S. Pyogenes bacteria. Nutmeg extract with $25 \mathrm{mg} / \mathrm{ml}$ concentration produced a $19,16 \mathrm{~mm}$ diameter on S. Aureus bacteria and 20,66 mm on S. Pyogenes bacteria. While nutmeg extract with $12,5 \mathrm{mg} / \mathrm{ml}$ concentration prodyced a $16,16 \mathrm{~mm}$ diameter on $\mathrm{S}$. Aureus bacteria and 18,16 mm on S. Pyogenes bacteria. Conclusion: Nutmeg extract has a potential inhibition effect on the growth of S. Aureus and S. Pyogenes bacteria. The inhibition effect of nutmeg extract is stronger on S. Pyogenes than S. Aureus.
\end{abstract}

Keywords: antibacterial, nutmeg extract, staphylococcus aureus, streptococcus pyogenes.

\begin{abstract}
Abstrak: Masyarakat Indonesia khususnya di Sulawesi Utara sering menggunakan serbuk biji pala untuk pengobatan luka. Bakteri bersifat komensal yang hidup di kulit manusia, seperti bakteri Staphylococcus aureus dan Streptococcus pyogenes dapat menginfeksi luka terbuka terutama yang tidak dirawat dengan baik. Penelitian ini bertujuan untuk mengetahui uji daya hambat ekstrak ekstrak biji pala terhadap Staphylococcus aureus dan Streptococcus pyogenes. Jenis penelitian ialah eksperimental laboratorium dengan modifikasi Kirby-Bauer sumuran di Laboratorium Fitokimia dan Mikrobiologi Fakultas MIPA Universitas Sam Ratulangi,. Ekstrak biji pala diperoleh dari proses maserasi dengan etanol 96\%. Konsentrasi ekstrak kental yang digunakan ialah $100 \mathrm{mg} / \mathrm{ml}, 50 \mathrm{mg} / \mathrm{ml}, 25 \mathrm{mg} / \mathrm{ml}$, dan 12,5 mg/ml. Sefuroksim sebagai kontrol positif dan akuades sebagai kontrol negatif. Hasil peneltiian memperlihatkan bahwa akuades tidak mempunyai zona hambat. Sefuroksim memiliki diameter zona hambat yang paling besar. Rerata diameter zona hambat yang dihasilkan oleh sefuroksim adalah $37,33 \mathrm{~mm}$ terhadap bakteri S.aureus dan $42,67 \mathrm{~mm}$ pada bakteri S.pyogenes. Ekstrak biji pala konsentrasi $100 \mathrm{mg} / \mathrm{ml}$ menghasilkan diameter zona hambat sebesar 25,16 mm pada bakteri S.aureus dan 24,16 mm pada bakteri S.pyogenes. Ekstrak biji pala konsentrasi $50 \mathrm{mg} / \mathrm{ml}$ sebesar $21 \mathrm{~mm}$ pada bakteri S.aureus dan 23,16 mmpada bakteri
\end{abstract}


S.pyogenes. Ekstrak biji pala konsentrasi $25 \mathrm{mg} / \mathrm{ml}$ sebesar $19,16 \mathrm{~mm}$ pada bakteri S.aureus dan 20,66 mmpada bakteri S.pyogenes. Sedangkan ekstrak biji pala konsentrasi 12,5 mg/ml sebesar 16,16 mm pada bakteri S.aureus dan 18,16 mmpada bakteri S.pyogenes. Simpulan: Ekstrak biji pala berpotensi memiliki efek daya hambat terhadap pertumbuhan bakteri S.aureus dan S.pyogenes. Daya hambat ekstrak biji pala lebih besar pada S.pyogenes daripada S.aureus.

Kata kunci: antibakteri, ekstrak biji pala, staphylococcus aureus, streptococcus pyogenes.

Indonesia dihuni oleh berbagai suku dengan pengetahuan pengobatan tradisional yang berbeda-beda. ${ }^{1,2}$ Masyarakat Indonesia turun temurun menggunakan obat tradisional sebagai warisan leluhur. ${ }^{3}$

Biji pala (Myristica fragrans Houtt.) dimanfaatkan oleh masyarakat Sulawesi Utara untuk pengobatan luka. Biji pala mengandung senyawa fenol, terpenoid, flavonoid, yang berpotensi sebagai antibakteri. $^{3}$

Bakteri bersifat komensal yang hidup di kulit manusia, seperti bakteri Staphylococcus aureus dan Streptococcus pyogenes bisa menjadi patogen pada keadaan tertentu yang dapat menginfeksi luka terbuka terutama yang tidak dirawat dengan baik. ${ }^{4}$ Bakteri Staphylococcus aureus dan Streptococcus pyogenes dapat menyebabkan infeksi kulit impetigo, folukulitis, erisipelas, dan selulitis. ${ }^{5,6}$

Berdasarkan informasi diatas, penulis ingin mengetahui apakah ada daya hambat dari ekstrak biji pala (Myristica fragrans) terhadap pertumbuhan bakteri Staphylococcus aureusdan Streptococcus pyogenes.

\section{METODE PENELITIAN}

Penelitian eksperimental laboratorium ini dilakukan di Laboratorium Fitokimia dan Mikrobiologi Program studi Farmasi FMIPA Universitas Sam Ratulangi. Penelitian ini dilaksanakan pada bulan Agustus sampai dengan November 2016.

Tahap-tahap penelitian ialah sterilisasi alat, pembuatan ekstrak daun srikaya dengan cara maserasi, pembuatan media peremajaan Nutrient Agar (NA), MullerHinton Agar (MHA), suspensi bakteri dan pengujian bakteri. Sefuroksim sebagai kontrol positif sedangkan akuades sebagai kontrol negatif. Ekstrak biji pala dengan berbagai konsentrasi $(100 \mathrm{mg} / \mathrm{ml}, 50$ $\mathrm{mg} / \mathrm{ml}, 25 \mathrm{mg} / \mathrm{ml}, 12,5 \mathrm{mg} / \mathrm{ml}$ ), kontrol positif dan kontrol negatif diteteskan sebanyak $50 \mu 1$ pada sumur yang berbeda, kemudian cawan petri dimasukkan dalam inkubator pada suhu $37^{\circ} \mathrm{C}$ selama $18-24$ jam. Diamati dan diukur diameter zona hambat yang terbentuk dengan menggunakan mistar satuan milimeter, pada 2 kali pengamatan yakni 18 jam inkubasi dan 24 jam inkubasi.

Zona bening merupakan petunjuk kepekaan bakteri terhadap bahan antibakteri yang digunakan sebagai bahan uji dan dinyatakan dengan diameter zona hambat. Diameter zona hambat dapat diukur dengan rumus:


Gambar 1. Biji Pala (Myristica fragrans Houtt.) 


\section{HASIL PENELITIAN}

Hasil pengujian daya hambat ekstrak daun patikan kerbau terhadap pertumbuhan Staphylococcus aureus dan Streptococcus pyogenes pada pengamatan 18 jam dan 24 jam inkubasi dengan 3 kali pengulangan menunjukan hasil yang positif. Hal ini ditunjukkan dengan terbentuknya zona jernih disekitar sumuran kontrol positif dan ekstrak biji pala. Sekitar sumuran kontrol negatif tidak terbentuk zona jernih.
Hasil pengujian daya hambat ekstrak biji pala terhadap pertumbuhan Staphylococcus aureus dan Streptococcus pyogenes pada pengamatan $3 \times 24$ jam inkubasi dengan 3 kali pengulangan memiliki nilai positif. Hal ini ditunjukkan dengan adanya clear zone disekitar sumuran kontrol positif dan ekstrak srikaya. Sekitar sumuran kontrol negatif tidak terbentuk clear zone.

A. Pengamatan 1 dilakukan pada waktu inkubasi 18 jam, yaitu pukul 13.00 WITA.

Tabel 1. Diameter zona hambat kontrol dan perlakuan pada bakteri S.aureus dan S.pyogenes pada pengamatan 1

\begin{tabular}{|c|c|c|c|c|c|c|c|c|c|c|c|c|}
\hline \multirow[b]{2}{*}{$\mathrm{P}$} & \multirow[b]{2}{*}{$\mathrm{K}-$} & \multicolumn{5}{|c|}{ Staphylococcus aureus } & \multirow[b]{2}{*}{$\mathrm{K}-$} & \multicolumn{5}{|c|}{ Streptococcus pyogenes } \\
\hline & & $\mathrm{K}+$ & $\begin{array}{c}100 \\
\mathrm{mg} / \\
\mathrm{ml}\end{array}$ & $\begin{array}{c}50 \\
\mathrm{mg} / \\
\mathrm{ml}\end{array}$ & $\begin{array}{c}25 \\
\mathrm{mg} / \\
\mathrm{ml}\end{array}$ & $\begin{array}{c}12,5 \\
\mathrm{mg} / \\
\mathrm{ml}\end{array}$ & & $\mathrm{K}+$ & $\begin{array}{c}100 \\
\mathrm{mg} / \\
\mathrm{ml}\end{array}$ & $\begin{array}{c}50 \mathrm{mg} \\
/ \mathrm{ml}\end{array}$ & $\begin{array}{c}25 \\
\mathrm{mg} / \\
\mathrm{ml}\end{array}$ & $\begin{array}{c}12,5 \\
\mathrm{mg} / \\
\mathrm{ml}\end{array}$ \\
\hline $\mathrm{I}$ & 0 & 35 & 24 & 16 & 14 & 13,5 & 0 & 38,5 & 16,5 & 15,5 & 14 & 13,5 \\
\hline II & 0 & 34 & 21,5 & 14,5 & 14,5 & 13 & 0 & 39 & 17,5 & 16 & 16 & 14,5 \\
\hline III & 0 & 35 & 22 & 17,5 & 14 & 13,5 & 0 & 40 & 16,5 & 15 & 14,5 & 13 \\
\hline Rerata & 0 & 34,33 & 22,5 & 16 & 14,16 & 13,33 & 0 & 39,16 & 16,83 & 15,5 & 14,83 & 13,66 \\
\hline
\end{tabular}

Keterangan : P. pengulangan; K-. kontrol negatif; K+. kontrol positif; $100 \mathrm{mg} / \mathrm{ml}$. konsentrasi 100 $\mathrm{mg} / \mathrm{ml} ; 50 \mathrm{mg} / \mathrm{ml}$. konsentrasi $50 \mathrm{mg} / \mathrm{ml} ; 25 \mathrm{mg} / \mathrm{ml}$. konsentrasi $25 \mathrm{mg} / \mathrm{ml} ; 12,5 \mathrm{mg} / \mathrm{ml}$. konsentrasi $12,5 \mathrm{mg} / \mathrm{ml}$.

B. Pengamatan 2 dilakukan pada waktu inkubasi 24 jam, yaitu pukul 19.00 WITA.

Tabel 1. Diameter zona hambat kontrol dan perlakuan pada bakteri S.aureus dan S.pyogenes pada pengamatan 2

\begin{tabular}{|c|c|c|c|c|c|c|c|c|c|c|c|c|}
\hline \multirow[b]{2}{*}{$\mathrm{P}$} & \multirow[b]{2}{*}{ K- } & \multicolumn{5}{|c|}{ Staphylococcus aureus } & \multirow[b]{2}{*}{ K- } & \multicolumn{5}{|c|}{ Streptococcus pyogenes } \\
\hline & & $\mathrm{K}+$ & $\begin{array}{c}100 \\
\mathrm{mg} / \\
\mathrm{ml}\end{array}$ & $\begin{array}{c}50 \mathrm{mg} / \\
\mathrm{ml}\end{array}$ & $\begin{array}{c}25 \\
\mathrm{mg} / \\
\mathrm{ml}\end{array}$ & $\begin{array}{c}12,5 \\
\mathrm{mg} / \\
\mathrm{ml}\end{array}$ & & $\mathrm{K}+$ & $\begin{array}{c}100 \\
\mathrm{mg} / \\
\mathrm{ml}\end{array}$ & $\begin{array}{c}50 \\
\mathrm{mg} / \\
\mathrm{ml}\end{array}$ & $\begin{array}{c}25 \\
\mathrm{mg} / \\
\mathrm{ml}\end{array}$ & $\begin{array}{c}12,5 \\
\mathrm{mg} / \\
\mathrm{ml}\end{array}$ \\
\hline $\mathrm{I}$ & 0 & 37 & 26 & 21,5 & 19,5 & 15,5 & 0 & 42,5 & 24 & 23,5 & 20 & 17,5 \\
\hline II & 0 & 36,5 & 24,5 & 21,5 & 19,5 & 16,5 & 0 & 43 & 24,5 & 22,5 & 21 & 17,5 \\
\hline III & 0 & 38,5 & 25 & 20 & 18,5 & 16,5 & 0 & 42,5 & 24 & 23,5 & 21 & 19,5 \\
\hline Rerata & 0 & 37,33 & 25,16 & 21 & 19,16 & 16,16 & 0 & 42,67 & 24,16 & 23,16 & 20,66 & 18,16 \\
\hline
\end{tabular}

\section{BAHASAN}

Berdasarkan hasil penelitian yang dilakukan pada tiga kali pengulangan terhadap bakteri Staphylococcus aureus dan Streptococcus pyogenes dalam dua kali pengamatan yaitu 18 jam dan 24 jam, zona hambat yang terbentuk setelah 18 jam masa inkubasi, terlihat jelas namun lebih kecil dibandingkan pengamatan setelah 24 jam inkubasi.

Akuades sebagai kontrol negatif tidak memperlihatkan adanya zona hambat yang terbentuk disekitar sumur. Pemilihan akuades sebagai kontrol negatif karena merupakan larutan pengencer pada kontrol positif maupun ekstrak biji pala. Akuades sebagai kontrol negatif membuktikan bahwa larutan pengencer tidak berpengaruh 
sebagai antimikroba.

Zona hambat kontrol positif yaitu sefuroksim pada kedua bakteri terlihat bening dan lebih besar dibanding kelompok perlakuan. Zona hambat sefuroksim mengalami peningkatan pada waktu inkubasi 24 jam pada kedua bakteri Staphylococcus aureus dan Streptococcus pyogenes. Sefuroksim yang merupakan antibiotik spektrum luas dengan cara kerja menghambat sintesis dinding sel mampu menghambat perkembangbiakan bakteri disekitar sumuran sehingga terlihat pada hasil, zona hambat yang terbentuk lebih besar. $^{7}$

Berdasarkan hasil pengamatan yang dilakukan pada kelompok perlakuan, terjadi peningkatan rerata diameter zona hambat seiring dengan meningkatnya konsentrasi ekstrak ekstrak biji pala $(100 \mathrm{mg} / \mathrm{ml}>50$ $\mathrm{mg} / \mathrm{ml}>25 \mathrm{mg} / \mathrm{ml}>12,5 \mathrm{mg} / \mathrm{ml}$ ) pada kedua bakteri Staphylococcus aureus dan Streptococcus pyogenes. Dengan begitu dapat dilihat seiring dengan bertambahnya konsentrasi ekstrak akan bertambah pula zona hambat. ${ }^{8}$ Hal ini sependapat dengan Harvey, yang mengatakan bahwa kosentrasi suatu bahan uji antibakteri dapat mempengaruhi zona hambat yang terbentuk pada sekitaran lubang sumuran. Semakin tinggi konsentrasi zat antibakteri maka memungkinkan semakin banyak pula sel mikroorganisme yang dihambat perkembangbiakannya. ${ }^{9}$

Lebar diameter zona hambat yang terbentuk di sekitar sumur dapat menjadi parameter untuk melihat kekuatan senyawa bioaktif dalam ekstrak biji pala. Semakin lebar zona hambat yang terbentuk mengindikasikan semakin kuatnya senyawa bioaktif yang menghambat perkembangbiakan bakteri. ${ }^{10,11}$ Penghambatan pertumbuhan bakteri dipengaruhi oleh senyawa aktif yang terdapat pada biji pala. Kandungan senyawa fenolik dan terpenoid dalam biji pala diduga dapat menghambat pertumbuhan berbagai jenis bakteri. ${ }^{3}$ Konsentrasi yang lebih tinggi memiliki senyawa aktif yang lebih banyak sehingga zona hambat yang terbentuk akan lebih besar sampai mencapai kadar daya maksimumnya.

Penelitian Galuh SK dkk, tahun 2003 tentang uji aktivitas penghambatan minyak atsiri dari ekstrak biji pala terhadap bakteri Xanthomonas campestris menunjukkan ekstrak biji pala memiliki aktivitas penghambatan pada konsentrasi 100 $\mathrm{mg} / \mathrm{ml} .{ }^{12}$ Penelitian mengenai pala juga pernah dilakukan oleh Thanoon SG dkk tahun 2013 tentang efek antibakteri dari minyak atsiri biji pala terhadap bakteri Staphylococcus aureus. Hasil penelitian ini menunjukkan konsentrasi 5\% dari minyak atsiri biji pala memiliki aktivitas antibakteri terhadap bakteri Staphylococcus aureus. ${ }^{13}$ Penelitian lain yang dilakukakn oleh Lawal TO dkk tahun 2014 menunjukkan tanaman pala memiliki daya hambat terhadap beberapa bakteri diantaranya Staphylococcus aureus dan Streptococcus pyogenes. ${ }^{14}$

Demikian juga dengan penelitian yang peneliti lakukan sekarang ini berdasarkan zona hambat yang terbentuk, ekstrak biji pala dapat menghambat pertumbuhan bakteri namun dalam penelitian ini peneliti menguji empat konsentrasi ekstrak biji pala yang beberbeda dan bakteri yang digunakan ialah bakteri Staphylococcus aureus dan Streptococcus pyogenes .

\section{SIMPULAN}

Dari hasil penelitian ini disimpulkan bahwa ekstrak biji pala memiliki daya hambat terhadap pertumbuhan bakteri Staphylococcus aureus dan Streptococcus pyogenes, tetapi zona hambatnya lebih kecil dibandingkan dengan antibiotik sefuroksim. Lama waktu inkubasi dan konsentrasi ekstrak mempengaruhi zona hambat yang terbentuk.

\section{DAFTAR PUSTAKA}

1. Hidayat S. Ramuan Tradisional Ala 12 Etnis Indonesia. Edisi ke-1. Jakarta: PPS; 2005. h. 12-13.

2. Muktiningsih SR, Muhammad HS, Harsana IW, Budhi M, Panjaitan P. Review Tanaman Obat yang Digunakan Oleh Pengobatan Tradisional di Sumatera Utara, 
Sulawesi Selatan, Bali, dan Sumatera Selatan. Media Litbang Kesehatan.2010;6:25-36.

3. Rachmi W, Zanuri A, Yuharmen. Perbandingan Isolasi Minyak Atsiri Biji Pala Cara Hidrodistilasi dan konvensional serta uji akitivitas antibakteri dan antioksidan. JOM FMIPA. 2014;1:335-342.

4. Brooks GF, Carroll KC, Butel JS, Morse SA, Mietzner TA. Mikrobiologi Kedokteran Jawetz, Melnick \& Adelberg. Edisi ke-25. Jakarta: EGC; 2012. h. 194-211.

5. Soedarto. Mikrobiologi Kedokteran. Edisi ke-1. Jakarta: Sagung Seto; 2015. h. 194-221.

6. Johnson AG, Ziegler RJ, Hawley L. Mikrobiologi dan Imunologi. Edisi ke-5. Jakarta: Binarupa Aksara; 2011. h. $79-152$

7. Gan VH, Istiantoro YH. Penisilin, Sefalosporin, dan Antibiotik Betalaktam Lainnya. Dalam: Gunawan SG, Nafrialdi RS, Elysabeth. Farmakologi dan Terapi. Edisi ke-5. Jakarta: FKUI; 2007. h. 596-7, 681-6.

8. Bachtiar SY, Tjahjaningsih W, Sianita N. Pengaruh Ekstrak Alga Cokelat Terhadap Pertumbuhan Bakteri Escherichia coli. Journal of Marine and Coastal Science. 2012;1:53-60.

9. Harvey RA, Champe PC, Fisher BD. Microbiology. 2nd ed.Philadelpia: Lippincot Williams \& Wilkins; 2007. p. 31-5.

10. Lay, Bibiana W, Hastowo, Sugyo. Mikrobiologi. Jakarta: Rajawali Press;1992. h.32.

11. Suharto, Chatim A. Fisiologi Pertumbuhan Kuman. Dalam: Staf Pengajar Bagian Mikrobiologi FKUI. Buku Ajar Mikrobiologi Kedokteran. Edisi revisi. Jakarta: Binarupa Aksara; 2011. h.33-37.

12. Rachmi W, Zanuri A, Yuharmen. Perbandingan Isolasi Minyak Atsiri Biji Pala Cara Hidrodistilasi dan konvensional serta uji akitivitas antibakteri dan antioksidan. JOM FMIPA. 2014;1:335-342.

13. Galuh SK, Suranto, Setianingsih R. Aktivitas Penghambatan Minyak Atsiri dan Ekstrak Kasar Biji Pala Terhadap Pertumbuhan Bakteri Xanthomonas campestris. Biofarmasi. 2003;1:20-24.

14. Thanoon SG, Al-Refai AS, Kamal A. Antibacterial effect and healing potential of nutmeg oil for chemically induced oral ulceration in rabbits. J. Med. Sci. 2013;17:393-9. 